\title{
Aquaculture and Restoration: Perspectives from Mediterranean Sea Experiences
}

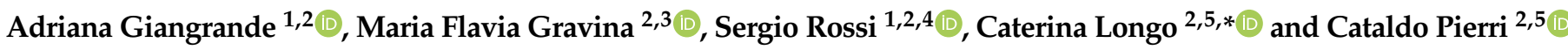 \\ 1 DiSTeBA, Department of Biological and Environmental Sciences and Technologies, University of Salento, \\ 73100 Lecce, Italy; adriana.giangrande@unisalento.it (A.G.); sergio.rossi@unisalento.it (S.R.) \\ 2 CoNISMa, Consorzio Nazionale Interuniversitario per le Scienze del Mare, 00196 Rome, Italy; \\ maria.flavia.gravina@uniroma2.it (M.F.G.); cataldo.pierri@uniba.it (C.P.) \\ Department of Biology, University of Rome "Tor Vergata", 00133 Rome, Italy \\ 4 Instituto de Ciencia do Mar, Labomar, Universidade Federal do Ceará, 60165-081 Fortaleza, Brazil \\ 5 Department of Biology, University of Bari Aldo Moro, 70125 Bari, Italy \\ * Correspondence: caterina.longo@uniba.it; Tel.: +39-080-5443357
}

check for updates

Citation: Giangrande, A.; Gravina, M.F.; Rossi, S.; Longo, C.; Pierri, C. Aquaculture and Restoration: Perspectives from Mediterranean Sea Experiences. Water 2021, 13, 991. https://doi.org/10.3390/w13070991

Academic Editor: Akintunde O. Babatunde

Received: 4 March 2021

Accepted: 1 April 2021

Published: 4 April 2021

Publisher's Note: MDPI stays neutral with regard to jurisdictional claims in published maps and institutional affiliations.

Copyright: (c) 2021 by the authors. Licensee MDPI, Basel, Switzerland. This article is an open access article distributed under the terms and conditions of the Creative Commons Attribution (CC BY) license (https:// creativecommons.org/licenses/by/ $4.0 /)$.
Abstract: In this paper, the different possibilities and innovations related to sustainable aquaculture in the Mediterranean area are discussed, while different maricultural methods, and the role of Integrated Multi-Trophic Aquaculture (IMTA) in supporting the exploitation of the ocean's resources, are also reviewed. IMTA, and mariculture in general, when carefully planned, can be suitable for environmental restoration and conservation purposes. Aquaculture, especially mariculture, is a sector that is progressively increasing in parallel with the increase in human needs; however, several problems still affect its development, mainly in relation to the choice of suitable sites, fodder production, and the impact on the surrounding environment. A current challenge that requires suitable solutions is the implementation of IMTA. Unfortunately, some criticisms still affect this approach, mostly concerning the commercialization of new products such as invertebrates and seaweeds, notwithstanding their environmentally friendly character. Regarding the location of a suitable site, mariculture plans are currently displaced from inshore to offshore, with the aim of reducing the competition for space with other human activities carried out within coastal waters. Moreover, in open water, waste loading does not appear to be a problem, but high-energy waters increase maintenance costs. Some suggestions are given for developing sustainable mariculture in the Mediterranean area, where IMTA is in its infancy and where the scarce nutrients that characterize offshore waters are not suitable for the farming of both filter feeder invertebrates and macroalgae. From the perspective of coupling mariculture activity with restoration ecology, the practices suggested in this review concern the implementation of inshore IMTA, creating artificially controlled gardens, as well as offshore mussel farming coupled with artificial reefs, while also hypothesizing the possibility of the use of artificially eutrophized areas.

Keywords: mariculture; underwater gardens; artificial reefs; bioremediation; sponge gardens

\section{Introduction}

The rapid growth of the human population is one of the main causes of the huge global changes that we are facing [1] due to the increasing human activities that are deeply altering the environment, with variable impacts on the world's oceans [2,3]. This population increase is also creating a greater demand for food, leading to the overexploitation of resources, particularly for animal consumption, impacting species worldwide and causing environmental degradation. Natural cycles may not be able to cope with such an increase and, as a result of industrialized fishing, the populations of many seafood species have declined by $80-90 \%$ [4,5]. At the same time, in recent years, the restoration of degraded marine ecosystems has become a pivotal issue in environmental policies focused on the protection and conservation of the ocean's resources. The farming of aquatic organisms 
originated at least 4000 years ago, focused on food production [6], and was only very recently employed in order to assist with marine restoration, a practice often referred to as artificial/controlled gardening [7].

Aquaculture, especially mariculture, represents the fastest-growing form of food production [8] and a possible sector of the EU's Blue Growth Strategy for boosting economic growth in Europe; for this reason, national aquaculture strategies are currently being developed [9]. However, several problems affect mariculture, the main ones being the environmental impact, the types of farmed species, fodder production, and the choice of suitable sites [10]. Notwithstanding these drawbacks, this sector remains one of the most sustainable for producing animal protein. Moreover, aquaculture, which is historically recognized as being responsible for localized environmental impacts, could have a hidden potential to achieve both conservation and the restoration of marine ecosystems, thereby identifying more sustainable ways to exploit the ocean's resources and to produce food for the growing global population, generating a positive ecological and social impact [11]. As an example, the production of bivalves and seaweeds requires balanced energy requirements, no additional food, and produces minimal greenhouse gas emissions [12]. Moreover, shellfish and seaweed farming can improve water quality and provide new substrates to increase local biodiversity, thereby creating a healthier ecosystem for marine life. The positive effects of bivalve farming on the surrounding environment have been highlighted both in water columns and sediment populations and dynamics, with the possible use of bivalve aquaculture as a restoration and remediation tool for marine environments [13]. In particular, marine production coupled with restoration was successfully applied in oyster reef restoration, which was proven to have multiple positive effects [14]. Therefore, if carefully designed, mariculture has the potential to take a step beyond simply reducing environmental impacts, instead becoming part of an effective strategy to facilitate the restoration of rocky reefs $[15,16]$.

However, to date, production-restoration coupling is still in its infancy and has been rarely exploited from commercial and environmental points of view-so much so that mariculture still represents a large problem that must be faced, resulting in the need for a series of initiatives to encourage harmonization and the development of common regulations between all countries, including in relation to the definition of common environmental standards for site selection $[17,18]$.

In the present paper, we review the possibility of coupling mariculture production with the protection and restoration of marine habitats in the Mediterranean, which rank among the main challenges of the XXI century from the perspective of the sustainable management of the ocean's resources.

\section{Marine Restoration}

The importance of preserving (and restoring) marine habitats was recently highlighted by Watson et al. [13], who estimated the natural capital value of the water quality of temperate marine systems. Marine restoration is mainly focused on important habitatforming species, which are threatened both by human interference [19] and mass mortality events [20]. The objective is to restore the "structural components" of the ecosystem, which means protecting habitat-forming species so that biodiversity and ecological services are assured. Key examples include coral reef restoration in tropical waters [21] and the restoration of algal (e.g., Cystoseira spp.) and Posidonia oceanica meadows [22], as well as marine sponge communities [23] in the Mediterranean Sea. Protection and restoration involving coral and seagrass meadows are linked to their importance in the provision of important fishery habitats and to the sequestration of a high quantity of $\mathrm{CO}_{2}$ from the atmosphere [24].

Today, active coral reef restoration is a popular practice and includes what is commonly referred to as artificial/controlled gardening [7]. This involves collecting and rehabilitating naturally broken coral fragments, propagating colonies, culturing larvae, or transplanting living colonies $[25,26]$. Nurseries for coral production are maintained as 
genetic repositories during natural mortality events. Coral farmers are active in relation to both fast-growing branching corals with a rapid rate of calcification and species that suffer intense degradation [27]. In areas where the reef has been lost, structural restoration is required, using other organisms (apart from corals) and involving the realization of artificial reefs.

In the Mediterranean, sponges form peculiar marine landscapes, defined as "spongegardens", which support a high abundance of species and biodiversity (Figure 1a) [28-33]. The conservation and restoration of such communities are essential to preserving a functioning ecosystem. With the aim of sustainably managing this resource, sponge transplantation experiments, together with restocking and rearing attempts in threatened and vulnerable species of commercial interest, have been carried out, with such studies showing limited mortality and positive growth among targeted species [34-43]. Transplantation experiments involving the overexploited and threatened Spongia officinalis along the Ionian Apulian coast (South Italy) showed the high vitality and reproductive integrity of the implanted sponges. Explants, collected from a wild population and implanted into an area where the species recently disappeared, showed a survival rate of $100 \%$ over one year [23,44]. The employed transplantation techniques were appropriate for promoting sponge restocking programs and reducing the risk of local extinction. The reintroduction of the species in depleted areas and the restoration of the nuclei of breeding populations are solid bases for management strategies within conservation policies.

In coastal areas, seaweed and seagrass, together with sponges, polychaetes, gorgonians, hard corals, bryozoans, bivalves, etc., contribute to realizing marine animal forests (MAF), which represent a high percentage of biodiversity hotspots, harboring suspensionfeeding organisms that form erect canopies like trees or shrubs on land [45]. Marine forests immobilize blue carbon and offer diverse ecosystem services [46,47]. The role of suspension-feeding organisms, as carbon immobilizers, and the process of removing carbon from the atmosphere, are discussed more deeply by Rossi and Rizzo [48].

So-called smart enhanced reefs (SER) can be planned to increase the volume of substrates in order to facilitate the recruitment and/or transplantation of sessile organisms (algae, sponges, corals, gorgonians, etc.) and can be designed to adapt to different marine ecosystems and the specific needs of the key species (sessile or vagile) [48]. These reefs are specially designed to allow for underwater gardening (sensu Rinkevich [25]) for conservation and productivity purposes, as well as to increase sustainable tourism [49]. As a whole, underwater gardening creates networks of structures with optimal conditions for reefs and marine life to regenerate ocean life by combining technology, education, science, and tourism. 


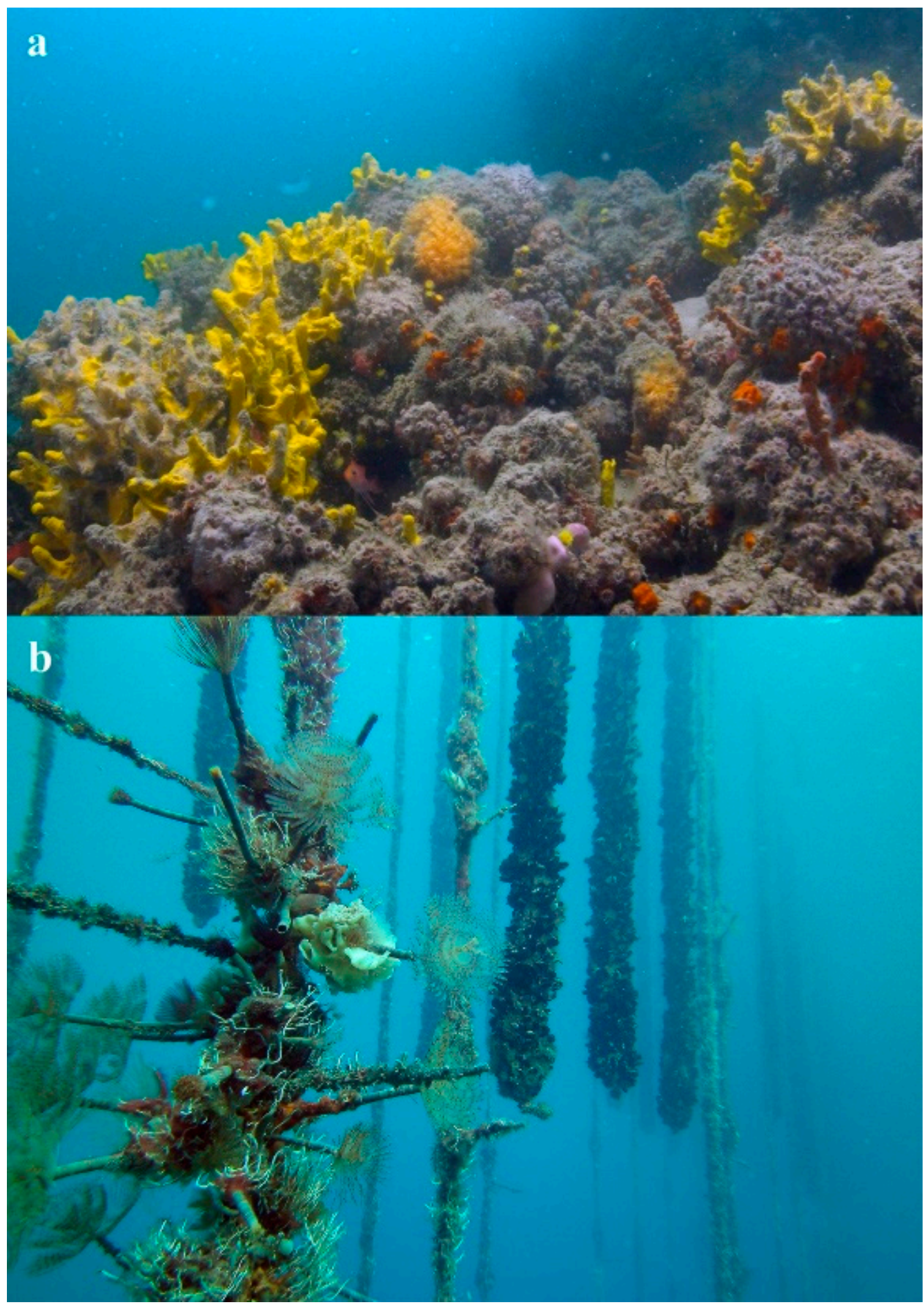

Figure 1. Genuine and induced peculiar marine landscape in the Mediterranean Sea: (a) image of a natural sponge garden in the Southern Adriatic Sea; $(\mathbf{b})$ vertical collectors placed around fish cages hosting a dense and rich filter feeder community.

\section{Production and Restoration}

Coupling production for human consumption with restorative aspects is a more recent approach. Early tentative attempts in this direction concern fishery sustained through habitat protection measures and restoration improved by aquaculture-based enhancement [50]. Aquaculture has long been associated with its environmental impacts, since uneaten food, feces, and fish excretion products can have negative impacts on the 
marine environment, consisting of the benthic community suffering from eutrophication as a consequence of the amount of waste released and the capacity for assimilation in the recipient water body [51,52]. Thus, the potential restorative effects of aquaculture on the environment are unexpected. By contrast, in recent studies, aquaculture coupled with habitat restoration resulted in positive impacts on ecological, economic, and social needs [53]. As an example, many bivalve shellfish reduce the organic load of the water by feeding on both phytoplankton and particulate organic matter. This extractive sequestration of nutrients produces water quality and clarity improvements [54-56]. Mussel, clam, and oyster aquaculture can also provide fish habitats, thereby enhancing benthic community diversity [57-59]. Moreover, seaweed aquaculture may mitigate the local effects of ocean acidification via the photosynthetic uptake of carbon dioxide $[60,61]$.

Therefore, shellfish and seaweed farms can have restorative benefits for ocean health and, at the same time, economic development, leading to societal benefits, food security, and greater food production in coastal areas worldwide [62-64], despite the fac that ecosystem services still need to be appropriately recognized and assessed. In other words, when managed at the ecological level, aquaculture provides increased benefits to the ecosystem via several ecosystem services $[65,66]$. The concept of restoration coupled with aquaculture was recently highlighted with regard to the farming of some engineer species that provide critical ecosystem services. The success of oyster reef restoration calls for research in this direction $[67,68]$. The habitat loss of oysters is one of the most dramatic examples of negative human impacts on marine ecosystems. Alongside the loss of oyster beds, we also lost a large ecosystem component capable of immobilizing huge amounts of carbon [69]. Therefore, the restoration of this habitat produced multiple benefits, in terms of both ecosystem services and market-based solutions, to ensure the sustainability of the sector [14]. Offshore mussel farming can also be incorporated into aquaculture restoration. This activity, when performed on a large scale, could be a means for carbon sequestration that may also mitigate global warming. Mussel production was the first and most extensive mollusk aquaculture in Europe. Mussels require no artificial food since they assimilate in situ primary production, and they grow rapidly, thereby promoting nutrient assimilation [70,71]. Together with mussel farms, so-called 3D ocean farming should also be mentioned as a case of productive activity with relevant implications for restoration. Such ocean farms are polyculture systems aimed at diversified species that are farmed together, the result being a reduction in the eutrophication impact and the production of large amounts of edible biomass. As they mimic the functions of a reef, they foster the regeneration and restoration of life in the sea. Green ocean farming is highly developed in Northern Europe (https:/ / www.greenoceanfarming.co.uk/ (accessed on 5 February 2021)), particularly kelp farming, and is mainly aimed at the production of marine vegetables. From this point of view, kelp farming provides alternative edible biomass, saving a large quantity of arable freshwater crops and avoiding fertilizer use. Seaweeds grow more quickly than land plants and sequester more carbon, thereby preventing ocean warming and reducing ocean acidification. Kelp also helps to remove some of the nitrogen originating from human activities, capturing unwanted substances causing hypoxia and algal blooms, which harm aquatic life. This type of mariculture can also be a solution to the key issue of the destination of stored carbon, which is released back into the atmosphere after decomposition. By contrast, a significant amount of $\mathrm{CO}_{2}$ removal can be achieved if biomass is used in environmentally friendly ways.

Underwater gardens are also effectively developed within the Integrated MultiTrophic Aquaculture (IMTA) philosophy, in which vertical structures are deployed around fish cages, resulting in strong bioremediation activity, together with an increase in biodiversity [43]. The IMTA is a very flexible concept that gives additional value to underwater plants based on the appropriate choice of organisms with complementary functions within the ecosystem (and with relevant economic value). The benefits of an integrated approach also include the recycling of waste by producing valuable biomass as a by-product, with 
consequently minimal impacts and the opportunity to farm fish in a suitable environment in a highly effective manner [72,73].

\section{Mariculture Development: Inshore vs. Offshore}

The main problems concerning mariculture are linked to the increased space required and the environmental impact of intensive production. The first issue is especially relevant along coasts with a high population density, such as those in the Mediterranean, where aquaculture may be forced to compete with other activities, particularly tourism; the second issue concerns fodder production in particular, which is particularly relevant due to the high amounts of protein required to satisfy the carnivorous diets of farmed fish. Therefore, a paradox occurs in which pelagic fish are overfished in order to produce the fodder required for mariculture demands, leading to the supply of wild pelagic fish becoming ecologically unsustainable. For this reason, finding different species and alternative protein sources was the goal of recent studies [74-76].

Concerning the space itself, the drivers for its expansion in the open sea are indeed mainly competition with other human coastal activities, coupled with the quality of the environment. Therefore, in many countries, there is increased interest in moving aquaculture production offshore, to areas within national exclusive economic zones [77].

Today, inshore mariculture production seems to be a practice that is well established around the world in shallow waters with low hydrodynamic energy, close to mainlandsupporting infrastructure [78]. It is mainly carried out between 1 and $7 \mathrm{~km}$ from the coastline [79]. Offshore mariculture requires cages positioned in deeper and less sheltered waters, away from the coast $[80,81]$, a practice that requires new technologies and the development of systems to avoid the strong currents, winds, and waves of more open areas. Indeed, to contrast the high-energy offshore environment, structures must be more robust than those utilized inshore [80], with submerging cages or shellfish culture systems minimizing and reducing the wave effects and interference caused by boating and shipping [80,82]. The cost of maintaining an offshore system is higher than that of inshore systems. Buck et al. [83] suggested that the definition of "offshore" should not refer to the distance from the coast, but rather to the hydrodynamic conditions. Therefore, "offshore aquaculture" indicates the transfer of farm installations from a sheltered environment to a site that is more exposed to marine weather conditions. The growing interest in moving large-scale aquaculture to the open ocean has made offshore aquaculture an innovative research field, requiring solutions to cope with the harshness of the exposed environment, with changes in farming protocols in order to adapt them to exposed, offshore conditions [84]

By moving away from coastal waters, reducing the pressure on nearshore ecosystems, offshore mariculture can be seen as a possible step towards the large-scale expansion of marine food production. Indeed, offshore aquaculture can provide more space to expand production, avoiding conflicts that occur with other possible uses of the coast in more crowded inshore waters [81]. This is especially true in countries with few suitable inshore sites [82]. Moreover, offshore aquaculture can also be linked to the multi-functional use of sites-for example, coupling aquaculture with energy production, as occurs in roaming plants with large mobile cages that are able to take advantage of ocean currents [85].

The "dilution of nutrients" that occurs offshore is also a strong reason to move coastal aquaculture to the open ocean [86]. Waste from offshore aquaculture is considered more diluted because it is swept away from the site. Offshore aquaculture may therefore reduce environmental impacts, thereby solving stakeholder conflicts [87-89]. However, the ecological impacts of offshore aquaculture are still largely unknown [80], and the capacity for ecosystems to assimilate waste from offshore aquaculture is yet to be defined [81,88-91]. The impact depends on the flushing rate and size of the farm, with some studies indicating low negative environmental impacts and others suggesting that nutrients released from offshore fish cages may be concentrated in locations far from the point of release [92,93].

By contrast, the organic load from inshore plants, which produces a large negative impact, is well known [94,95], so inshore mariculture requires more attention to be paid 
to the treatment of waste from the plants when discharged in the water. At present, the IMTA techniques are attempting to solve this problem [96-98]. The IMTA combines the cultivation of fed species with species extracting organic and inorganic substances to create balanced systems for both environmental and economic sustainability [99]. In such systems, the waste that comes from the production of fish can be converted into by-products that can also be utilized in fodder production, creating a circular economy. From an economic point of view, the IMTA systems, which provide different cultured products, i.e., fish and other inexpensive species, have marginal impacts per unit of fish produced and are economically advantageous to production, insofar as they promote a circular economy. Nowadays, however, integrated approaches focus only on "economically" viable species such as edible filter feeders [96,98,100]. Experimentation on other extractive organisms of valuable biomass is therefore desirable, as in the case of filter feeder polychaetes, whose biomass can be utilized in different fields, including fodder production [43,101].

In the planning of IMTA systems, profound knowledge of the environmental and biological characteristics of the area is required [102-106]. The biological characteristics of the local communities are not to be underestimated because their structure and dynamics are linked to the success of the polyculture. Rather than trying to randomly breed species, it is useful to look for the most suitable and abundant species to avoid having to fight a losing battle against fouling. In fact, in a traditional fish plant, fouling on the nets is considered a negative factor [107] and is repeatedly removed through management operations such as the changing of fish cage nets and structures. Fouling is often an obstacle that is difficult to overcome, as in the case of the breeding of algal species or sessile invertebrates, e.g., porifera, polychaetes, and ascidians $[43,106]$. In the case of mollusk farming, fouling removal operations are made easier by the possibility of periodically exposing the product to the air (mussels) or by mechanical removal, which is required due to the presence of a hard and resistant shell (oysters). The possibility of removing fouling by hand would require increased expenditure in terms of labor and time, which is traditionally incompatible with production. From another perspective, it seems more effective to follow the natural trend of the ecological succession of macrobenthic communities, selecting the most frequently occurring and abundant species in the area to be reared in a polyculture. As an example, the fouling associated with aquaculture facilities in different geographic areas in Southern Italy has resulted in different species compositions, with mollusks being the dominant species (Mytilus galloprovincialis), alongside polychaetes (Sabella spallanzanii), ascidians, and bryozoans [106]. Therefore, the choice of the species that should be bred based on the knowledge of local biodiversity can transform fouling from a threat into a resource.

Offshore IMTA is well developed, especially in extra-Mediterranean areas, where large plants combining fish and macroalgae can be found. Moreover, in many countries around the world, there is increased interest in moving mussel farms offshore [77]. In high-energy marine environments, mussel cultures are realized with longlines submerged in middle depths $[108,109]$.

New strategies are also being investigated, such as multi-use platforms, combining mussel farming with other activities such as offshore wind energy [88,91,110-115]. Openwater shellfish farms have been shown to be environmentally benign and to provide a greater economic return than fishing, recreation, or conservation alone. Mussels constitute a good and cheap source of animal protein and other nutrients [116]. Therefore, mussel production is not only a cheap and healthy source of food but can also improve the quality of the water and the carbon sequestration.

Unfortunately, offshore mussel farming is not common in the Mediterranean Sea [117,118] since its open waters are nutrient-poor and unsuitable for filter feeder farming [119].

\section{Integrated Aquaculture and Artificial Reefs in the Mediterranean Area: Problems and Perspectives}

The Mediterranean marine ecosystem is characterized by some unique specific environmental features, such as the high temperature of the water column, which fosters the 
rapid growth of fish with production throughout the year; the microtidal regime, which reduces water renewal in enclosed bays with weak currents; oligotrophic conditions with low primary productivity; low levels of phytoplankton biomass; low quantities of particulate organic matter; and high levels of oxygen, excluding a few exceptions, such as the Adriatic and some areas with riverine inputs. All of these conditions are favorable for fish farming in submerged cages, but not for mussel farming and macroalgae cultivation. Mussel farming is highly developed in Central Mediterranean areas (from Spain to Greece) and is especially realized in confined environments and along the west coast of the Adriatic [120]. For a long time, this activity was restricted to coastal lagoons, with several limits, such as the necessity of the intensification of production and the industrial and domestic pollution that often occurs in sites such as this, which experience limited water renewal due to a lack of strong tides, often inducing dystrophic crisis and anoxia. As an example, the historical renown of Taranto mussels (South Italy) over the last decade has suffered following policy decisions to relocate a portion of mussel farmers outside of the Mar Piccolo. The resulting decline in mussel quality and the question of how Taranto mussel production could be restored have become focal issues as a result [120], with the currently hypothesized solution involving the occupation of a space in the open sea.

According to Buck et al. [83], IMTA in nearshore water bodies has grown exponentially and it is time to shift our focus to offshore areas. In many areas, including the Mediterranean, the IMTA is unfortunately still in an embryonic phase, even in its nearshore state, and many issues still need to be resolved. For example, it is necessary to verify the local legislative constraints relating to licenses and functionalities for IMTA operations, as well as to address the perception and the market of stakeholders. Similar problems have been partially solved in relation to salmon farming in the Northern Atlantic [121]. A crucial issue concerns the certification of products obtained from IMTA systems, e.g., the development of standards for the definition of a certification system that can be accepted by consumers and industry. Lastly, many operators are against the IMTA system since they do not foresee fast economic feedback and do not consider IMTA to be a good economic investment. As a whole, we are still very far from large-scale plants and from a market where new products can be introduced, especially in the Mediterranean, where the integrated marine production system is still poorly diffused, at an experimental stage, or already operating via inshore plants. However, we are at the beginning of one of the most stimulating challenges for the blue economy.

In the oligotrophic Mediterranean offshore waters, offshore fishing production could be implemented via the coupling of filter feeder invertebrate and macroalgae farming, both of which can find nutrition from the waste created by fish cages.

However, concerning the development of the Mediterranean IMTA, we believe that this system can be implemented in confined areas and coupled with restoration. In this way, artificial structures can be utilized that mimic hard substrates and create gardens covered with typical species found within confined environments, such as filter feeder polychaetes, sponges, and ascidians. These reef structures could be realized both on the bottom of (hard bottom reefs under the cages of fish) and within the water column as vertical collectors (3-D reefs) positioned around the cages (Figure 1b). The presence of these vertical structures can increase both the local biodiversity and production of the area via the elimination of waste, which can be transformed into biomass of economic value. The filtration activity carried out by filter feeders that settle on the vertical collectors can reduce the supply of nutrients that sink to the bottom, creating better conditions in the benthic environment and producing exploited biomass that can be collected in each reproductive cycle, while the organisms colonizing the bottom of the structure can act as a larval supply for vertical collectors. Moreover, the placement of artificial structures at the bottom of the water column could transform a degraded area, utilized for productive purposes, into an area in which underwater tourism can also be implemented (Figure 2a,b). 


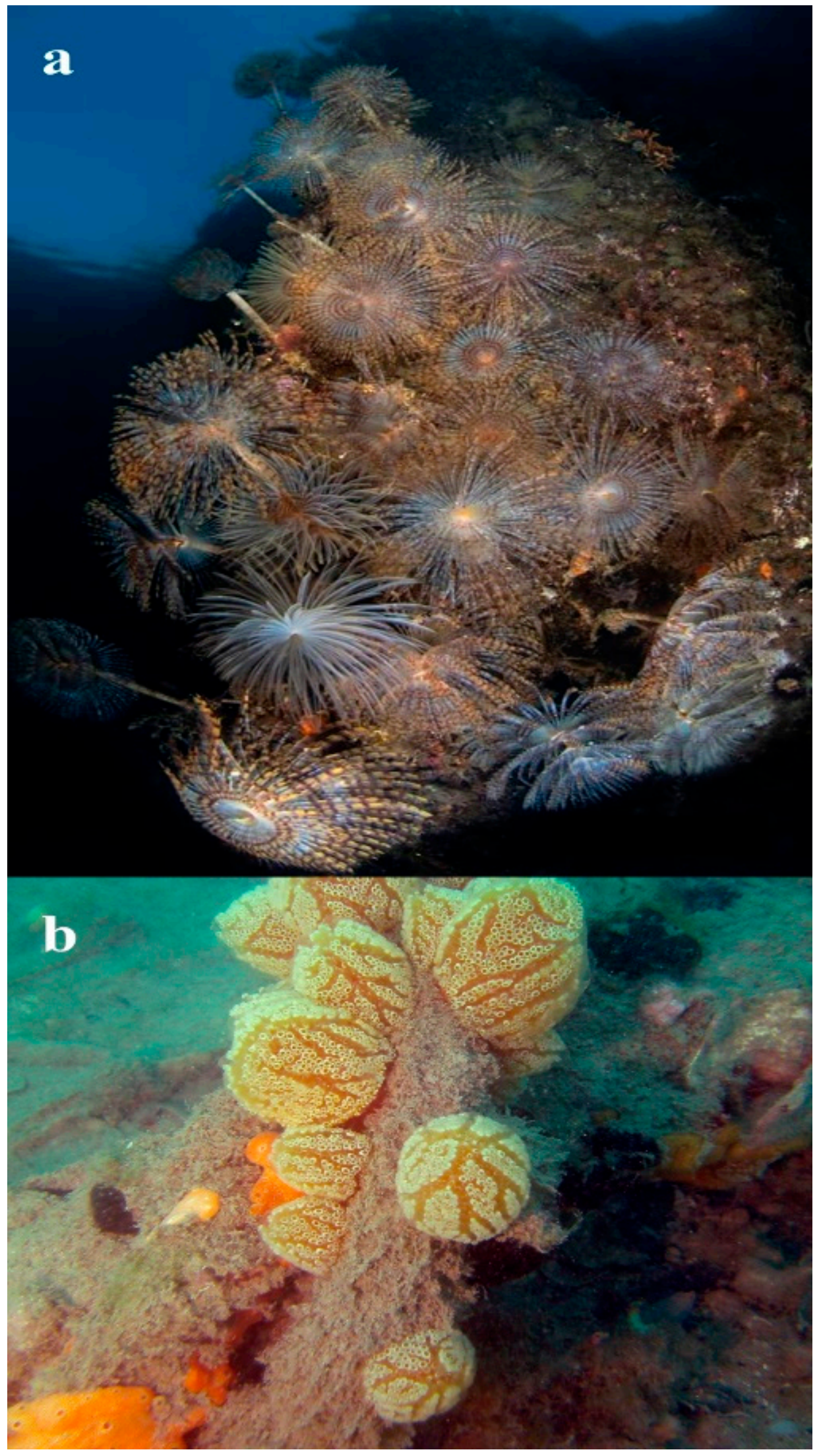

Figure 2. Artificial hard substrata around mariculture in a biodiversity hotspot: (a) a rich polychaetes community, mainly made up of Sabella spallanzanii (photo: courtesy of Gianluca Romano); (b) a dense tunicates population with numerous specimens of Distaplia cfr bermudensis. 
Underwater gardens, which, as already mentioned, are largely developed in the Mediterranean, particularly for sponges, consist precisely of the use of artificial structures that act to restore and create new habitats, increasing biodiversity and performing carbon sequestration. The first scientific studies on artificial structures date back to the 1970s, when artificial reefs were positioned on soft bottoms within three miles of the coast in order to prevent damage by trawl fishing. Historically, artificial reefs have been used around the world to attract and capture fish for human consumption. In the Mediterranean Sea, the first artificial reefs were created in the 1500s when fishermen left rocks used to anchor tuna fishing nets on the seabed at the end of each fishing season. These structures created new rocky habitats that became inhabited by fish and were subsequently exploited by local fishers between the tuna fishing seasons [122]. Similar practices have likely been employed across the world [123] throughout history. The modern concept of artificial reefs was adopted in the Mediterranean in the second half of the 1900s. Today, more than 300 artificial reefs are deployed in the Mediterranean and the Black Sea, with the main purpose being to enhance fisheries and improve fishery management [124-126]. Therefore, as with supply-side ecology, which was defined as "old wine in a new bottle", gardening and restoration linked to aquaculture with the use of artificial structures is a new application of the artificial structure philosophy [126-131]. Artificial structures applied to sustainable aquaculture can act as nursery areas, protecting the bottom from illegal fishery, increasing wild fish populations, protecting biodiversity, and creating recreational activities.

The increasing interest in artificial reefs also leads to possible negative impacts by the use of unsuitable materials; therefore, guidelines have been developed to support the placement of artificial reefs in European seas [132-135]. The General Fisheries Commission for the Mediterranean (GFCM) of the Food and Agriculture Organization of the United Nations (FAO) discussed the use of artificial reefs in the Mediterranean and the Black Sea for the management of fisheries and fishing resources [136].

Artificial reefs can also be associated with the implementation of mussel farming in open Mediterranean waters. As already mentioned, offshore mussel production in the Mediterranean can be limited by the oligotrophic conditions of the waters, which can be an obstacle for the adoption of extensive open-sea mussel farms and seaweed cultivation. In the Mediterranean basin, offshore mollusk production took place mainly in France and in the Northern Adriatic area. In Italy, the first installations were set up more than 50 years ago in the Gulf of Trieste (Northern Adriatic Sea) using suspension culture technologies similar to those used in the Atlantic [117,118]. Experiments were also carried out in the central Adriatic Sea (Conero Promontory, Ancona province) to assess the potential of producing mussels (M. galloprovincialis) and oysters (Crassostrea gigas) in submerged structures coupled with artificial reefs, where traditional shellfish farming is not possible [137-139]. The base units of the reef consist of 10-15 $\mathrm{m}$ of pyramidal piles of concrete blocks with holes of different diameters, connected with nets to collect the mussel seeds from longline systems. The structures were colonized naturally with wild mussel propagules. A reef of 116 pyramids can produce an average of around 260 tons of mussels each year.

Finally, the fertilization of offshore oligotrophic areas for macroalgae and mussel farming may also be possible. This method has been hypothesized, considering phytoplankton as an environmental engineer whose increases, through ocean iron fertilization (OIF), could mitigate global warming [140]. This hypothesis is based on the reasoning that adding traces of iron to the iron-limited phytoplankton of the ocean will lead to blooms and the sequestration of significant amounts of atmospheric carbon dioxide by the sinking of organic matter in the deep sea and sediments. The hypothesis was further tested [141,142], indicating that the efficacy and side effects of OIF differ according to the area, so adequately designed experiments are needed for realistic parametrization. Experiments with mussel farms, or even with the cultivation of macroalgae, could be performed in some offshore Mediterranean areas on a small scale after ecological monitoring establishing the trophic conditions and nutrient cycles of the area. Indeed, large volumes of dissolved nutrients 
could have an impact on phytoplankton composition and the potential of producing algae blooms, including toxic species [143,144].

\section{Conclusions}

Mediterranean coasts are densely populated and the high level of competition for coastal space utilization suggests that production being moved offshore is the best solution. This is also in agreement with the scarcity of nutrients in Mediterranean waters, which can be overcome by coupling offshore fishing production with the farming of filter feeder invertebrates and macroalgae feeding on the waste from the cages. Such productive activities are in agreement with the sustainability criteria, which also foster $\mathrm{CO}_{2}$ sequestration, notwithstanding the fact that the shift from inshore to offshore plants requires investment and new technology. The changeover of inshore production plants, which cause environmental pressure, to IMTA coupled with the creation of underwater gardens can lead to the restoration of the habitat as a whole. This, of course, requires good knowledge of the autochthonous benthic-pelagic coupling, as well as native fouling, in order to find suitable species.

Only a few examples of such IMTA plants are available, and very little is known about the restoration that they afford. The current example, which inspired the realization of this review, comes from the Remedia Life Project, which demonstrated that artificial structures employed in mariculture can increase the biodiversity of the area where the production occurs.

Artificial reefs can also be associated with the implementation of mussel farming in open Mediterranean waters. Placing filtering organisms in marine waters with suitable currents enables a high level of production per unit area and can also mitigate ocean acidification. Macroalgae and filter feeders feed on nutrients, as well as phytoplankton and particulate organic matter occurring in the seawater. Therefore, the employment of mussels and macroalgae for production leads to the sequestration of $\mathrm{CO}_{2}$ and the fertilization of oligotrophic areas.

Author Contributions: Conceptualization, A.G. and C.P.; writing—original draft preparation, A.G., M.F.G., S.R., C.L. and C.P.; writing—review and editing, M.F.G. and S.R.; supervision, A.G.; project administration, A.G. and C.L.; funding acquisition, A.G. and C.L. All authors have read and agreed to the published version of the manuscript.

Funding: This research was funded by the EUROPEAN COMMUNITY, Remedia Life Project LIFE16 $\mathrm{ENV} / \mathrm{IT} / 000343$.

Institutional Review Board Statement: Not applicable.

Informed Consent Statement: Not applicable.

Data Availability Statement: Data sharing not applicable.

Acknowledgments: The authors are indebted to Gianluca and Graziana Basile of Maricoltura del Mar Grande (Taranto, Italy), the mariculture company where the trials mentioned in this article are currently in progress.

Conflicts of Interest: The authors declare no conflict of interest.

\section{References}

1. Ripple, W.J.; Wolf, C.; Newsome, T.M.; Barnard, P.; Moomaw, W.R. World scientists' warning of a climate emergency. Bioscience 2020. [CrossRef]

2. Halpern, B.S.; Walbridge, S.; Selkoe, K.A.; Kappel, C.V.; Micheli, F.; D’Agrosa, C.; Bruno, J.F.; Casey, K.S.; Ebert, C.; Fox, H.E.; et al. A global map of human impact on marine ecosystems. Science 2008, 319, 948-952. [CrossRef] [PubMed]

3. Halpern, B.S.; Frazier, M.; Afflerbach, J.; Lowndes, J.S.; Micheli, F.; O'Hara, C.; Scarborough, C.; Selkoe, K.A. Recent pace of change in human impact on the world's ocean. Sci. Rep. 2019, 9, 11609. [CrossRef] [PubMed]

4. Baum, J.K.; Myers, R.A.; Kehler, D.G.; Worm, B.; Harley, S.J.; Doherty, P.A. Collapse and conservation of shark populations in the Northwest Atlantic. Science 2003, 299, 389-392. [CrossRef] [PubMed]

5. Myers, R.A.; Worm, B. Rapid worldwide depletion of predatory fish communities. Nature 2003, 423, 280-283. [CrossRef] 
6. Stickney, R.R.; Treece, G.D. History of aquaculture. In Aquaculture Production Systems; Tidwell, J.H., Ed.; Wiley-Blackwell: Oxford, UK, 2012; pp. 15-50.

7. Gallardi, D. Effects of bivalve aquaculture on the environment and their possible mitigation: A review. Fish. Aquac. J. 2014, 5, 1-8. [CrossRef]

8. FAO. The State of World Fisheries and Aquaculture 2020; Sustainability in action; FAO: Rome, Italy, 2020; ISBN 9789251326923.

9. Duarte, C.M.; Holmer, M.; Olsen, Y.; Soto, D.; Marbà, N.; Guiu, J.; Black, K.; Karakassis, I. Will the oceans help feed humanity? Bioscience 2009, 59, 967-976. [CrossRef]

10. Serpa, D.; Duarte, P. Impacts of aquaculture and mitigation measures. Dyn. Biochem. Process. Biotechnol. Mol. Biol. 2008, 2, 1-20.

11. Lozano, S.; Iribarren, D.; Moreira, M.T.; Feijoo, G. Environmental impact efficiency in mussel cultivation. Resour. Conserv. Recycl. 2010, 54, 1269-1277. [CrossRef]

12. Aubin, J.; Fontaine, C.; Callier, M.; Roque d'orbcastel, E. Blue mussel (Mytilus edulis) bouchot culture in Mont-St Michel Bay: Potential mitigation effects on climate change and eutrophication. Int. J. Life Cycle Assess. 2018, 23, 1030-1041. [CrossRef]

13. Watson, S.C.L.; Preston, J.; Beaumont, N.J.; Watson, G.J. Assessing the natural capital value of water quality and climate regulation in temperate marine systems using a EUNIS biotope classification approach. Sci. Total Environ. 2020, 744, 1-11. [CrossRef] [PubMed]

14. Bayraktarov, E.; Saunders, M.I.; Abdullah, S.; Mills, M.; Beher, J.; Possingham, H.P.; Mumby, P.J.; Lovelock, C.E. The cost and feasibility of marine coastal restoration. Ecol. Appl. 2016, 26, 1055-1074. [CrossRef] [PubMed]

15. Grabowski, J.H.; Peterson, C.H. Restoring oyster reefs to recover ecosystem services. In Theoretical Ecology Series; Academic Press: Cambridge, MA, USA, 2007; pp. 281-298.

16. Matthew, G. Fifteen Years of Rhode Island Oyster Restoration: A Performance Evaluation and Cost-Benefit Analysis. Ph.D. Thesis, University of Rhode Island, Kingston, RI, USA, 2016.

17. Karakassis, I. Environmental interactions and initiatives on site selection and carrying capacity estimation for fish farming in the Mediterranean. In Site Selection and Carrying Capacities for Inland and Coastal; Ross, L.G., Telfer, T.C., Falconer, L., Soto, D., Aguilar-Manjarrez, J., Eds.; FAO: Rome, Italy, 2013; pp. 160-170.

18. Alexander, K.A.; Potts, T.P.; Freeman, S.; Israel, D.; Johansen, J.; Kletou, D.; Meland, M.; Pecorino, D.; Rebours, C.; Shorten, M.; et al. The implications of aquaculture policy and regulation for the development of integrated multi-trophic aquaculture in Europe. Aquaculture 2015, 443, 16-23. [CrossRef]

19. Boström-Einarsson, L.; Babcock, R.C.; Bayraktarov, E.; Ceccarelli, D.; Cook, N.; Ferse, S.C.A.; Hancock, B.; Harrison, P.; Hein, M.; Shaver, E.; et al. Coral restoration-A systematic review of current methods, successes, failures and future directions. PLoS ONE 2020, 15, e022663. [CrossRef] [PubMed]

20. Fey, S.B.; Siepielski, A.M.; Nusslé, S.; Cervantes-Yoshida, K.; Hwan, J.L.; Huber, E.R.; Fey, M.J.; Catenazzi, A.; Carlson, S.M. Recent shifts in the occurrence, cause, and magnitude of animal mass mortality events. Proc. Natl. Acad. Sci. USA 2015, 112, 1083-1088. [CrossRef]

21. Epstein, N.; Bak, R.P.M.; Rinkevich, B. Applying forest restoration principles to coral reef rehabilitation. Aquat. Conserv. Mar. Freshw. Ecosyst. 2003, 13, 387-395. [CrossRef]

22. Tamburello, L.; Papa, L.; Guarnieri, G.; Basconi, L.; Zampardi, S.; Scipione, M.B.; Terlizzi, A.; Zupo, V.; Fraschetti, S. Are we ready for scaling up restoration actions? An insight from Mediterranean macroalgal canopies. PLoS ONE 2019, 14, e0224477. [CrossRef]

23. Baldacconi, R.; Cardone, F.; Longo, C.; Mercurio, M.; Nonnis Marzano, C.; Gaino, E.; Corriero, G. Transplantation of Spongia officinalis L. (Porifera, Demospongiae): A technical approach for restocking this endangered species. Mar. Ecol. Evol. Perspect. 2010, 31, 309-317. [CrossRef]

24. Macreadie, P.I.; Anton, A.; Raven, J.A.; Beaumont, N.; Connolly, R.M.; Friess, D.A.; Kelleway, J.J.; Kennedy, H.; Kuwae, T.; Lavery, P.S.; et al. The future of Blue Carbon science. Nat. Commun. 2019, 10, 1-13. [CrossRef]

25. Rinkevich, B. The active reef restoration toolbox is a vehicle for coral resilience and adaptation in a changing world. J. Mar. Sci. Eng. 2019, 7, 201. [CrossRef]

26. Rinkevich, B. Ecological engineering approaches in coral reef restoration. ICES J. Mar. Sci. 2020, 78, 410-420. [CrossRef]

27. Lirman, D.; Thyberg, T.; Herlan, J.; Hill, C.; Young-Lahiff, C.; Schopmeyer, S.; Huntington, B.; Santos, R.; Drury, C. Propagation of the threatened staghorn coral Acropora cervicornis: Methods to minimize the impacts of fragment collection and maximize production. Coral Reefs 2010, 29, 729-735. [CrossRef]

28. Beazley, L.I.; Kenchington, E.L.; Murillo, F.J.; Sacau, M.d.M. Deep-sea sponge grounds enhance diversity and abundance of epibenthic megafauna in the Northwest Atlantic. ICES J. Mar. Sci. 2013, 70, 1471-1490. [CrossRef]

29. Bo, M.; Bertolino, M.; Bavestrello, G.; Canese, S.; Giusti, M.; Angiolillo, M.; Pansini, M.; Taviani, M. Role of deep sponge grounds in the Mediterranean Sea: A case study in southern Italy. Hydrobiologia 2012, 687, 163-177. [CrossRef]

30. Gherardi, M.; Giangrande, A.; Corriero, G. Epibiontic and endobiontic polychaetes of Geodia cydonium (Porifera, Demospongiae) from the Mediterranean Sea. Hydrobiologia 2001, 443, 87-101. [CrossRef]

31. Gerovasileiou, V.; Chintiroglou, C.C.; Konstantinou, D.; Voultsiadou, E. Sponges as "living hotels" in Mediterranean marine caves. Sci. Mar. 2016, 80, 279-289. [CrossRef]

32. Goren, L.; Idan, T.; Shefer, S.; Ilan, M. Macrofauna inhabiting massive demosponges from shallow and mesophotic habitats along the israeli Mediterranean coast. Front. Mar. Sci. 2021, 7, 1-14. [CrossRef] 
33. Klitgaard, A.B. The fauna associated with outer shelf and upper slope sponges (Porifera, Demospongiae) at the Faroe islands, northeastern Atlantic. Sarsia 1995, 80, 1-22. [CrossRef]

34. Verdenal, B.; Vacelet, J. Sponge culture on vertical ropes in the Northwestern Mediterranean Sea. In New Perspectives in Sponge Biology; Rützler, K., Ed.; Smithsonian Institution Press: Washington, DC, USA, 1990; pp. 416-424.

35. Pronzato, R.; Bavestrello, G.; Cerrano, C.; Magnino, G.; Manconi, R.; Pantelis, J.; Sarà, A.; Sidri, M. Sponge farming in the Mediterranean Sea: New perspectives. Mem. Queensl. Mus. 1999, 44, 485-491.

36. Scalera Liaci, L.; Mercurio, M.; Palladino, F.; Massari, S.; Corriero, G. La spongicoltura: Una forma di maricoltura costiera compatibile con i vincoli di tutela delle aree protette. In Proceedings of the $29^{\circ}$ Congresso S.I.B.M., Ustica, Italy, $15-20$ June 1998.

37. Scalera Liaci, L.; Mercurio, M.; Palladino, F.; Massari, S.; Corriero, G. L'allevamento di spugne commerciali nella Riserva Marina di Porto Cesareo (LE). Biol. Mar. Mediterr. 1999, 6, 110-118.

38. Mercurio, M.; Longo, C.; Nonnis Marzano, C.; Scalera Liaci, L.; Corriero, G. L'allevamento di spugne commerciali nella Riserva Naturale Marina 'Isola di Ustica. ' Biol. Mar. Mediterr. 2003, 10, 462-464.

39. Corriero, G.; Longo, C.; Mercurio, M.; Nonnis Marzano, C.; Lembo, G.; Spedicato, M.T. Rearing performance of Spongia officinalis on suspended ropes off the Southern Italian Coast (Central Mediterranean Sea). Aquaculture 2004, 238, 195-205. [CrossRef]

40. Pronzato, R.; Manconi, R. Mediterranean commercial sponges: Over 5000 years of natural history and cultural heritage. Mar. Ecol. 2008, 29, 146-166. [CrossRef]

41. De Caralt, S.; Sánchez-Fontenla, J.; Uriz, M.J.; Wijffels, R.H. In situ aquaculture methods for Dysidea avara (demospongiae, porifera) in the Northwestern Mediterranean. Mar. Drugs 2010, 8, 1731-1742. [CrossRef]

42. $\quad$ van Treeck, P.; Eisinger, M.; Müller, J.; Paster, M.; Schuhmacher, H. Mariculture trials with Mediterranean sponge species: The exploitation of an old natural resource with sustainable and novel methods. Aquaculture 2003, 218, 439-455. [CrossRef]

43. Giangrande, A.; Pierri, C.; Arduini, D.; Borghese, J.; Licciano, M.; Trani, R.; Corriero, G.; Basile, G.; Cecere, E.; Petrocelli, A.; et al. An innovative IMTA system: Polychaetes, sponges and macroalgae co-cultured in a Southern Italian in-shore mariculture plant (Ionian Sea). J. Mar. Sci. Eng. 2020, 8, 733. [CrossRef]

44. Corriero, G.; Mercurio, M.; Nonnis Marzano, C.; Longo, C. Metodologia per la reintroduzione di poriferi in ambiente naturale. In Brevetto Nazionale Depositato Presso la Camera di Commercio Industria Artigianato Agricoltura di Bari; n. BA 2003 A000011; Ministero dello Sviluppo Economico: Rome, Italy, 2003.

45. Rossi, S. The destruction of the "animal forests" in the oceans: Towards an over-simplification of the benthic ecosystems. Ocean. Coast. Manag. 2013, 84, 77-85. [CrossRef]

46. Rossi, S.; Bramanti, L.; Gori, A.; Orejas, C. Animal forests of the world: An overview. In Marine Animal Forests: The Ecology of Benthic Biodiversity Hotspots; Springer: Cham, Switzerland, 2017; ISBN 9783319210124.

47. Paoli, C.; Montefalcone, M.; Morri, C.; Vassallo, P.; Bianchi, C.N. Ecosystem functions and services of the marine animal forests. In Marine Animal Forests: The Ecology of Benthic Biodiversity Hotspots; Springer: Cham, Switzerland, 2017 ; ISBN 9783319210124.

48. Rossi, S.; Rizzo, L. Marine animal forests as carbon immobilizers or why we should preserve these three-dimensional alive structures. In Perspectives on the Marine Animal Forests of the World; Springer: Cham, Switzerland, 2020.

49. Westoby, R.; Becken, S.; Laria, A.P. Perspectives on the human dimensions of coral restoration. Reg. Environ. Chang. 2020, 20, 1-13. [CrossRef]

50. Lorenzen, K.; Agnalt, A.L.; Blankenship, H.L.; Hines, A.H.; Leber, K.M.; Loneragan, N.R.; Taylor, M.D. Evolving context and maturing science: Aquaculture-based enhancement and restoration enter the marine fisheries management toolbox. Rev. Fish. Sci. 2013, 21, 213-221. [CrossRef]

51. Carroll, M.L.; Cochrane, S.; Fieler, R.; Velvin, R.; White, P. Organic enrichment of sediments from salmon farming in Norway: Environmental factors, management practices, and monitoring techniques. Aquaculture 2003, 1, 165-180. [CrossRef]

52. Karakassis, I.; Tsapakis, M.; Hatziyanni, E.; Papadopoulou, K.N.; Plaiti, W. Impact of cage farming of fish on the seabed in three Mediterranean coastal areas. ICES J. Mar. Sci. 2000, 57, 1462-1471. [CrossRef]

53. Theuerkauf, S.J.; Morris, J.A.; Waters, T.J.; Wickliffe, L.C.; Alleway, H.K.; Jones, R.C. A global spatial analysis reveals where marine aquaculture can benefit nature and people. PLOS ONE 2019, 14, e222282. [CrossRef] [PubMed]

54. Schröder, T.; Stank, J.; Schernewski, G.; Krost, P. The impact of a mussel farm on water transparency in the Kiel Fjord. Ocean. Coast. Manag. 2014, 101, 45-52. [CrossRef]

55. Rose, J.M.; Bricker, S.B.; Ferreira, J.G. Comparative analysis of modeled nitrogen removal by shellfish farms. Mar. Pollut. Bull. 2015, 91, 185-190. [CrossRef] [PubMed]

56. Higgins, C.B.; Stephenson, K.; Brown, B.L. Nutrient bioassimilation capacity of aquacultured oysters: Quantification of an ecosystem service. J. Environ. Qual. 2011, 40, 271-277. [CrossRef] [PubMed]

57. Tallman, J.C.; Forrester, G.E. Oyster grow-out cages function as artificial reefs for temperate fishes. Trans. Am. Fish. Soc. 2007, 136, 790-799. [CrossRef]

58. Kraufvelin, P.; Díaz, E.R. Sediment macrofauna communities at a small mussel farm in the northern Baltic proper. Boreal Environ. Res. 2015, 20, 378-390.

59. Chopin, T. Reducing the carbon footprint of ocean-derived food production (fisheries and aquaculture) and shifting diets: Another of the five opportunities to make the ocean part of the solution to climate change. Aquaculture 2020, 23, 12-13.

60. Mongin, M.; Baird, M.E.; Hadley, S.; Lenton, A. Optimising reef-scale CO2 removal by seaweed to buffer ocean acidification. Environ. Res. Lett. 2016, 11, 1-11. [CrossRef] 
61. Rabiei, R.; Phang, S.M.; Yeong, H.Y.; Lim, P.E.; Ajdari, D.; Zarshenas, G.; Sohrabipour, J. Bioremediation efficiency and biochemical composition of Ulva reticulata Forsskål (Chlorophyta) cultivated in shrimp (Penaeus monodon) hatchery effluent. Iran. J. Fish. Sci. 2014, 13, 621-639.

62. Gagnon, K.; Rinde, E.; Bengil, E.G.T.; Carugati, L.; Christianen, M.J.A.; Danovaro, R.; Gambi, C.; Govers, L.L.; Kipson, S.; Meysick, L.; et al. Facilitating foundation species: The potential for plant-bivalve interactions to improve habitat restoration success. J. Appl. Ecol. 2020, 57, 1161-1179. [CrossRef]

63. Ahmed, M.; Lorica, M.H. Improving developing country food security through aquaculture development-Lessons from Asia. Food Policy 2002, 27, 125-141. [CrossRef]

64. Aslan, L.O.M.; Iba, W.; Bolu, L.O.R.; Ingram, B.A.; Gooley, G.J.; de Silva, S.S. Mariculture in SE Sulawesi, Indonesia: Culture practices and the socio economic aspects of the major commodities. Ocean. Coast. Manag. 2015, 116, 44-57. [CrossRef]

65. Froehlich, H.E.; Gentry, R.R.; Halpern, B.S. Conservation aquaculture: Shifting the narrative and paradigm of aquaculture's role in resource management. Biol. Conserv. 2017, 215, 162-168. [CrossRef]

66. Alleway, H.K.; Gillies, C.L.; Bishop, M.J.; Gentry, R.R.; Theuerkauf, S.J.; Jones, R. The Ecosystem Services of Marine Aquaculture: Valuing Benefits to People and Nature. Bioscience 2019, 69, 59-68. [CrossRef]

67. Rodriguez-Perez, A.; James, M.; Donnan, D.W.; Henry, T.B.; Møller, L.F.; Sanderson, W.G. Conservation and restoration of a keystone species: Understanding the settlement preferences of the European oyster (Ostrea edulis). Mar. Pollut. Bull. 2019, 138, 312-321. [CrossRef]

68. Jaris, H.; Brown, D.S.; Proestou, D.A. Assessing the contribution of aquaculture and restoration to wild oyster populations in a Rhode Island coastal lagoon. Conserv. Genet. 2019, 20, 503-516. [CrossRef]

69. Thurstan, R.H.; Pandolfi, J.M.; zu Ermgassen, P.S.E. Animal forests through time: Historical data to understand present changes in marine ecosystems. In Marine Animal Forests: The Ecology of Benthic Biodiversity Hotspots; Rossi, S., Bramanti, L., Gori, A., Covadonga, O., Eds.; Springer International Publishing: Cham, Switzerland, 2017; pp. 947-963. ISBN 978-3-319-21012-4.

70. Cheney, D.; Langan, R.; Heasman, K.; Friedman, B.; Davis, J. Shellfish culture in the open ocean: Lessons learned for offshore expansion. Mar. Technol. Soc. J. 2010, 44, 55-67. [CrossRef]

71. Galimany, E.; Wikfors, G.H.; Dixon, M.S.; Newell, C.R.; Meseck, S.L.; Henning, D.; Li, Y.; Rose, J.M. Cultivation of the Ribbed Mussel (Geukensia demissa) for Nutrient Bioextraction in an Urban Estuary. Environ. Sci. Technol. 2017, 51, 13311-13318. [CrossRef]

72. Chopin, T. Global Aquaculture Advocate; GAA: Portsmouth, NH, USA, 2012.

73. Chopin, T. Integrated multi-trophic aquaculture-ancient, adaptable concept focuses on ecological integration. Glob. Aquac. Advocate 2013, 16, 16-19.

74. Olsen, Y. Resources for fish feed in future mariculture. Aquac. Environ. Interact. 2011, 1, 187-200. [CrossRef]

75. Olsen, R.L.; Hasan, M.R. A limited supply of fishmeal: Impact on future increases in global aquaculture production. Trends Food Sci. Technol. 2012, 27, 120-128. [CrossRef]

76. Belghit, I.; Liland, N.S.; Gjesdal, P.; Biancarosa, I.; Menchetti, E.; Li, Y.; Waagbø, R.; Krogdahl, Å.; Lock, E.J. Black soldier fly larvae meal can replace fish meal in diets of sea-water phase Atlantic salmon (Salmo salar). Aquaculture 2019, 503, 609-619. [CrossRef]

77. Mizuta, D.D.; Fregeau, M.; Dixon, M.S.; Maney, E.J.J.; Wikfors, G.H. Offshore mussel aquaculture: Strategies for farming in the changing environment of the Northeast U.S. shelf EEZ. Bull. Jpn. Fish. Res. Edu. Agency 2019, 49, 111-119.

78. Osmundsen, T.C.; Amundsen, V.S.; Alexander, K.A.; Asche, F.; Bailey, J.; Finstad, B.; Olsen, M.S.; Hernández, K.; Salgado, H. The operationalisation of sustainability: Sustainable aquaculture production as defined by certification schemes. Glob. Environ. Chang. 2020, 60, 1-8. [CrossRef]

79. Trujillo, P.; Piroddi, C.; Jacquet, J. Fish farms at Sea: The ground truth from Google Earth. PLoS ONE 2012, 10, e0134745. [CrossRef]

80. Naylor, R.; Burke, M. Aquaculture and ocean resources: Raising tigers of the sea. Annu. Rev. Environ. Resour. 2005, 30, 185-218. [CrossRef]

81. Sturrock, H.; Newton, R.; Paffrath, S.; Bostock, J.; Muir, J.; Young, J.; Immink, A.; Dickson, M. Prospective Analysis of the Aquaculture Sector in the EU; JRCEC: Seville, Spain, 2008; ISBN 9789279094415.

82. Lado-Insua, T.; Ocampo, F.J.; Moran, K. Offshore mussel aquaculture: New or just renewed? In Proceedings of the OCEANS '09 Balancing Technology with Future Needs, Bremen, Germany, 11-14 May 2009.

83. Buck, B.H.; Troell, M.F.; Krause, G.; Angel, D.L.; Grote, B.; Chopin, T. State of the art and challenges for offshore integrated multi-trophic aquaculture (IMTA). Front. Mar. Sci. 2018, 5, 165. [CrossRef]

84. Buck, B.H.; Grote, B. Seaweed in high-energy environments. Protocol to move Saccharina cultivation offshore. In Macroalagae Research; Charrier, B., Wichard, T., Reddy, C.R.K., Eds.; CRC Press: Boca Raton, FL, USA, 2018; pp. 4-36.

85. Mann, C.C. The Bluewater Revolution. Wired. 2004. Available online: https://www.wired.com/2004/05/fish/ (accessed on 5 February 2021).

86. Simpson, S. The blue food revolution. Sci. Am. 2011, 304, 54-61. [CrossRef]

87. Corbin, J.S. Marine aquaculture: Today's necessity for tomorrow's seafood. Mar. Technol. Soc. J. 2007, 41, 16-23. [CrossRef]

88. Troell, M.; Joyce, A.; Chopin, T.; Neori, A.; Buschmann, A.H.; Fang, J.G. Ecological engineering in aquaculture-Potential for integrated multi-trophic aquaculture (IMTA) in marine offshore systems. Aquaculture 2009, 297, 1-9. [CrossRef]

89. Gentry, R.R.; Froehlich, H.E.; Grimm, D.; Kareiva, P.; Parke, M.; Rust, M.; Gaines, S.D.; Halpern, B.S. Mapping the global potential for marine aquaculture. Nat. Ecol. Evol. 2017, 1, 1317-1324. [CrossRef] [PubMed] 
90. Ferreira, J.G.; Hawkins, A.J.S.; Monteiro, P.; Moore, H.; Service, M.; Pascoe, P.L.; Ramos, L.; Sequeira, A. Integrated assessment of ecosystem-scale carrying capacity in shellfish growing areas. Aquaculture 2008, 275, 138-151. [CrossRef]

91. Ferreira, J.G.; Sequeira, A.; Hawkins, A.J.S.; Newton, A.; Nickell, T.D.; Pastres, R.; Forte, J.; Bodoy, A.; Bricker, S.B. Analysis of coastal and offshore aquaculture: Application of the FARM model to multiple systems and shellfish species. Aquaculture 2009, 289, 32-41. [CrossRef]

92. Venayagamoorthy, S.K.; Ku, H.; Fringer, O.B.; Chiu, A.; Naylor, R.L.; Koseff, J.R. Numerical modeling of aquaculture dissolved waste transport in a coastal embayment. Environ. Fluid Mech. 2011, 11, 329-351. [CrossRef]

93. Løland, G. Current forces on, and water flow through and around, floating fish farms. Aquac. Int. 1993, 1, 72-89. [CrossRef]

94. Tomassetti, P.; Gennaro, P.; Lattanzi, L.; Mercatali, I.; Persia, E.; Vani, D.; Porrello, S. Benthic community response to sediment organic enrichment by Mediterranean fish farms: Case studies. Aquaculture 2016, 450, 262-272. [CrossRef]

95. Martinez-Garcia, E.; Carlsson, M.S.; Sanchez-Jerez, P.; Sánchez-Lizaso, J.L.; Sanz-Lazaro, C.; Holmer, M. Effect of sediment grain size and bioturbation on decomposition of organic matter from aquaculture. Biogeochemistry 2015, 125, 123-148. [CrossRef]

96. Hughes, A.D.; Black, K.D. Going beyond the search for solutions: Understanding trade-offs in European integrated multi-trophic aquaculture development. Aquac. Environ. Interact. 2016, 8, 191-199. [CrossRef]

97. Granada, L.; Sousa, N.; Lopes, S.; Lemos, M.F.L. Is integrated multitrophic aquaculture the solution to the sectors' major challenges?-A review. Rev. Aquac. 2016, 8, 283-300. [CrossRef]

98. Sarà, G.; Reid, G.K.; Rinaldi, A.; Palmeri, V.; Troell, M.; Kooijman, S.A.L.M. Growth and reproductive simulation of candidate shellfish species at fish cages in the Southern Mediterranean: Dynamic Energy Budget (DEB) modelling for integrated multitrophic aquaculture. Aquaculture 2012, 324-325, 259-266. [CrossRef]

99. Barrington, K.; Chopin, T.; Robinson, S. Integrated multitrophic aquaculture (IMTA) in marine temperate waters. In Integrated Mariculture; Soto, D., Ed.; FAO: Rome, Italy, 2009; Volume 529, ISBN 9789251063873.

100. Aguilar-Manjarrez, J.; Kapetsky, J.; Soto, D. The Potential of Spatial Planning Tools to Support the Ecosytem Approach to Aquaculture; FAO: Rome, Italy, 2010; ISBN 9789251064788.

101. Stabili, L.; Cecere, E.; Licciano, M.; Petrocelli, A.; Sicuro, B.; Giangrande, A. Integrated multitrophic aquaculture by-products with added value: The Polychaete Sabella spallanzanii and the Seaweed Chaetomorpha linum as Potential Dietary Ingredients. Mar. Drugs 2019, 17, 677. [CrossRef]

102. Navarrete-Mier, F.; Sanz-Lázaro, C.; Marín, A. Does bivalve mollusc polyculture reduce marine fin fish farming environmental impact? Aquaculture 2010, 306, 101-107. [CrossRef]

103. Mahmood, T.; Fang, J.; Jiang, Z.; Zhang, J. Carbon and nitrogen flow, and trophic relationships, among the cultured species in an integrated multi-trophic aquaculture (IMTA) bay. Aquac. Environ. Interact. 2016, 8, 207-219. [CrossRef]

104. Ning, Z.; Liu, S.; Zhang, G.; Ning, X.; Li, R.; Jiang, Z.; Fang, J.; Zhang, J. Impacts of an integrated multi-trophic aquaculture system on benthic nutrient fluxes: A case study in Sanggou Bay, China. Aquac. Environ. Interact. 2016, 8, 221-232. [CrossRef]

105. Sanz-Lazaro, C.; Sanchez-Jerez, P. Mussels do not directly assimilate fish farm wastes: Shifting the rationale of integrated multi-trophic aquaculture to a broader scale. J. Environ. Manag. 2017, 201, 82-88. [CrossRef] [PubMed]

106. Giangrande, A.; Lezzi, M.; Del Pasqua, M.; Pierri, C.; Longo, C.; Gravina, M.F. Two cases study of fouling colonization patterns in the Mediterranean Sea in the perspective of integrated aquaculture systems. Aquac. Rep. 2020, 18, 1-12. [CrossRef]

107. Bannister, J.; Sievers, M.; Bush, F.; Bloecher, N. Biofouling in marine aquaculture: A review of recent research and developments. Biofouling 2019, 35, 631-648. [CrossRef]

108. Buck, B.H. Experimental trials on the feasibility of offshore seed production of the mussel Mytilus edulis in the German Bight: Installation, technical requirements and environmental conditions. Helgol. Mar. Res. 2007, 61, 87-101. [CrossRef]

109. Buck, B.H.; Nevejan, N.; Wille, M.; Chambers, M.D.; Chopin, T. Offshore and multi-use aquaculture with extractive species: Seaweeds and bivalves. In Aquaculture Perspective of Multi-Use Sites in the Open Ocean: The Untapped Potential for Marine Resources in the Anthropocene; FAO: Rome, Italy, 2017; ISBN 9783319511597.

110. Buck, B.H.; Krause, G.; Rosenthal, H. Extensive open ocean aquaculture development within wind farms in Germany: The prospect of offshore co-management and legal constraints. Ocean. Coast. Manag. 2004, 47, 95-122. [CrossRef]

111. Buck, B.H.; Ebeling, M.W.; Michler-Cieluch, T. Mussel cultivation as a co-use in offshore wind farms: Potential and economic feasibility. Aquac. Econ. Manag. 2010, 14, 255-281. [CrossRef]

112. Griffin, R.; Buck, B.; Krause, G. Private incentives for the emergence of co-production of offshore wind energy and mussel aquaculture. Aquaculture 2015, 436, 80-89. [CrossRef]

113. Jansen, H.M.; Van Den Burg, S.; Bolman, B.; Jak, R.G.; Kamermans, P.; Poelman, M.; Stuiver, M. The feasibility of offshore aquaculture and its potential for multi-use in the North Sea. Aquac. Int. 2016, 24, 735-756. [CrossRef]

114. van den Burg, S.W.K.; Kamermans, P.; Blanch, M.; Pletsas, D.; Poelman, M.; Soma, K.; Dalton, G. Business case for mussel aquaculture in offshore wind farms in the North Sea. Mar. Policy 2017, 85, 1-7. [CrossRef]

115. Brenner, M.; Buchholz, C.; Heemken, O.; Buck, B.H.; Koehler, A. Health and growth performance of the blue mussel (Mytilus edulis L.) from two hanging cultivation sites in the German Bight: A nearshore-offshore comparison. Aquac. Int. 2012, 20, 751-778. [CrossRef]

116. Willett, W.; Rockström, J.; Loken, B.; Springmann, M.; Lang, T.; Vermeulen, S.; Garnett, T.; Tilman, D.; DeClerck, F.; Wood, A.; et al. Food in the Anthropocene: The EAT-Lancet Commission on healthy diets from sustainable food systems. Lancet 2019. [CrossRef] 
117. Tamburini, E.; Turolla, E.; Fano, E.A.; Castaldelli, G. Sustainability of mussel (Mytilus galloprovincialis) farming in the Po river delta, northern Italy, based on a life cycle assessment approach. Sustainability 2020, 12, 3814. [CrossRef]

118. Danioux, C.; Bompais, X.; Loste, C.; Paquotte, P.; Muir, J.; Basurco, B. Offshore mollusc production in the Mediterranean basin. In Mediterranean Offshore Mariculture; CIHEAMIAMZ-Options Méditerranéennes: Rome, Italy, 2000; Volume 30, pp. 115-140.

119. Cranford, P.J.; Reid, G.K.; Robinson, S.M.C. Open water integrated multi-trophic aquaculture: Constraints on the effectiveness of mussels as an organic extractive component. Aquac. Environ. Interact. 2013, 4, 163-173. [CrossRef]

120. Caroppo, C.; Giordano, L.; Palmieri, N.; Bellio, G.; Bisci, A.P.; Portacci, G.; Sclafani, P.; Hopkins, T.S. Progress toward sustainable mussel aquaculture in Mar Piccolo, Italy. Ecol. Soc. 2012, 17, 10. [CrossRef]

121. Ellis, J.; Tiller, R. Conceptualizing future scenarios of integrated multi-trophic aquaculture (IMTA) in the Norwegian salmon industry. Mar. Policy 2019, 104, 198-209. [CrossRef]

122. Riggio, S.; Badalamenti, F.; D'Anna, G. Artificial Reefs in Sicily: An Overview. In Artificial Reefs in European Seas; Springer: Cham, Switzerland, 2000.

123. Simard, F. Réflexions sur les récifs artificiels au Japon. Biol. Mar. Mediterr. 1995, 2, 99-109.

124. Bombace, G.; Fabi, G.; Fiorentini, L.; Speranza, S. Analysis of the efficacy of artificial reefs located in five different areas of the Adriatic Sea. Bull. Mar. Sci. 1994, 55, 559-580.

125. Fabi, G.; Sala, A. An assessment of biomass and diel activity of fish at an artificial reef (Adriatic sea) using a stationary hydroacoustic technique. ICES J. Mar. Sci. 2002, 59, 411-420. [CrossRef]

126. Relini, G.; Lanteri, L.; Franco, A.; Cimmino, C. Fishes of artificial reefs in the gulf of Genoa. In Proceedings of the 47th EMBS, Arendal, Norway, 3-7 September 2012; p. 129.

127. Ardizzone, G.D.; Gravina, M.F.; Belluscio, A. Temporal development of epibenthic communities on artificial reefs in the central Mediterranean Sea. Bull. Mar. Sci. 1989, 44, 592-608.

128. Gravina, M.F.; Ardizzone, G.D.; Belluscio, A. Polychaetes of an artificial reef in the central mediterranean sea. Estuar. Coast. Shelf Sci. 1989, 28, 161-172. [CrossRef]

129. Somaschini, A.; Ardizzone, G.D.; Gravina, M.F. Long-term changes in the structure of a polychaete community on artificial habitats. Bull. Mar. Sci. 1997, 60, 460-466.

130. Relini, G.; Orsi Relini, L. Artificial reefs in the Ligurian Sea (northwestern Mediterranean): Aims and results. Bull. Mar. Sci. 1989, $44,743-751$.

131. Relini, G.; Relini, M.; Palandri, G.; Merello, S.; Beccornia, E. History, ecology and trends for artificial reefs of the Ligurian sea, Italy. Hydrobiologia 2007, 13, 193-217.

132. OSPAR Commission. OSPAR Guidelines on Artificial Reefs in relation to Living Marine Resources; OSPAR 99/15/1-E, Annex 6; OSPAR Commission: Paris, France, 1999.

133. OSPAR Commission. Assessment of Construction or Placement of Artificial Reefs; OSPAR Commission: Paris, France, 2009 ; p. 27.

134. London Convention and Protocol. UNEP London Convention and Protocol/UNEP Guidelines for the Placement of Artificial Reefs; London Convention and Protocol: London, UK, 2009; p. 303.

135. UNEP-MAP. UNEP-MAP Guidelines for the Placement at Sea of Matter for Purpose Other than the Mere Disposal (Construction of Artificial Reefs); UNEP-MAP: Athens, Greece, 2005.

136. GFCM. FAO General Fisheries Commission for the Mediterranean Report of the Thirty-Fourth Session; GFCM: Athens, Greece, 2010.

137. Bombace, G.; Fabi, G.; Fiorentini, L. Artificial reefs in the Adriatic sea. In Artificial Reefs in European Seas; Jensen, A.C., Collins, K.J., Lockwood, A.P.M., Eds.; Springer: Dordrecht, The Netherlands, 2000; pp. 31-63. ISBN 978-94-011-4215-1.

138. Fabi, G.; Spagnolo, A. Artificial reefs and mariculture. In Proceedings of the NATO Advanced Reserch Work of Mode Aquatic. Coast Zoessons Opportunity, Porto, Portugal, 14-17 September 1998; pp. 91-98.

139. Fabi, G.; Manoukian, S.; Spagnolo, A. Impact of an open-sea suspended mussel culture on macrobenthic community (Western Adriatic Sea). Aquaculture 2009, 289, 54-63. [CrossRef]

140. Martin, J.H. Glacial-interglacial CO2 change: The Iron Hypothesis. Paleoceanography 1990. [CrossRef]

141. Smetacek, V.; Naqvi, S.W.A. The next generation of iron fertilization experiments in the Southern Ocean. Philos. Trans. R. Soc. A Math. Phys. Eng. Sci. 2008, 366, 3947-3967. [CrossRef] [PubMed]

142. Smetacek, V.; Klaas, C.; Strass, V.H.; Assmy, P.; Montresor, M.; Cisewski, B.; Savoye, N.; Webb, A.; D’Ovidio, F.; Arrieta, J.M.; et al. Deep carbon export from a Southern Ocean iron-fertilized diatom bloom. Nature 2012, 487, 313-319. [CrossRef] [PubMed]

143. Folke, C.; Kautsky, N.; Troell, M. The Costs of Eutrophication from Salmon Farming: Implications for Policy. J. Environ. Manag. 1994, 40, 173-182. [CrossRef]

144. Glibert, P.; Burford, M. Globally changing nutrient loads and harmful algal blooms: Recent advances, new paradigms, and continuing challenges. Oceanography 2017, 30, 58-69. [CrossRef] 